\title{
A literature review on the parvovirus B19 infection in sickle cell anemia and $\beta$ - thalassemia patients
}

\author{
Saber Soltani ${ }^{1}$, Armin Zakeri ${ }^{2}$, Alireza Tabibzadeh ${ }^{3}$, Milad Zandi ${ }^{1}$, Elham Ershadi ${ }^{1}$, Sara Akhavan Rezayat ${ }^{4}$
} Sanaz Khaseb ${ }^{2}$, Amir mohammad Zakeri ${ }^{5}$, Mohammadvala Ashtar Nakhaei ${ }^{6}$, Shervin Afzali ${ }^{6}$ and Abbas Farahani ${ }^{7^{*}}$ (D)

\begin{abstract}
Background: Parvovirus B19 is the causative agent for erythema infectiosum, and also as a potentially lifethreatening infectious agent, it is mainly presented in high erythrocyte turnover patients. Sickle cell disease (SCD) is an inherited monogenic hematological disorder resulting from the mutations in the hemoglobin $\beta$-chain gene. Thalassemia is a hereditary hematological syndrome that happens in consequence of deficiencies in the production of one or more globin chains. We summarize current knowledge about the prevalence rates of the parvovirus B19 infection in sickle cell anemia and thalassemia patients.

Methods: Several online databases were searched including, Scopus, EMBASE, Web of Science, Google Scholar, and PubMed, which were performed amidst 2009-2019 by using distinct keywords: "Thalassemia," "Parvovirus," "Anemia, " "Sickle cell anemia," "parvoviridae," "parvoviridae infection," and "parvovirus B19."

Results: Search results indicated 4 and 7 studies for the prevalence of the parvovirus B19 in $\beta$-thalassemia and SCD, respectively. Among the $\beta$-thalassemia patients, the B19V seroprevalence for $\lg G$ and $\lg M$ were ranged from 18.2$81 \%$ and $14.5-41.1 \%$, respectively; meanwhile, B19V DNA positively results was $4-15.3 \%$. Moreover, in the SCD group, the extent of B19V IgG was varied from 37.6 to $65.9 \%$ and that of $\operatorname{lgM}$ was in a range of $2.9-30 \%$, and the DNA detection rate was 4-54\%.

Conclusion: B19V seroprevalence changes in several conditions including, different epidemiological features, socioeconomic status, and overpopulation. Age can expand the incidence of anti-B19V IgG/lgM in SCD and betathalassemia patients. Reinfection and diverse genotypes are relevant factors in the seroprevalence of B19v. The patients' immunological-hematological station and higher abundance of transfusions can affect the B19V seroprevalence in SCD and beta-thalassemia group. Further investigations in this field could be suggested to better understand the virus distribution in this susceptible population of patients.
\end{abstract}

Keywords: Parvovirus B19, Sickle cell anemia, $\beta$-thalassemia

\footnotetext{
* Correspondence: abbasfarahani25@yahoo.com

${ }^{7}$ Infectious and Tropical Diseases Research Center, Hormozgan Health

Institute, Hormozgan University of Medical Sciences, Bandar Abbas, Iran

Full list of author information is available at the end of the article
}

(c) The Author(s). 2020 Open Access This article is licensed under a Creative Commons Attribution 4.0 International License, which permits use, sharing, adaptation, distribution and reproduction in any medium or format, as long as you give appropriate credit to the original author(s) and the source, provide a link to the Creative Commons licence, and indicate if changes were made. The images or other third party material in this article are included in the article's Creative Commons licence, unless indicated otherwise in a credit line to the material. If material is not included in the article's Creative Commons licence and your intended use is not permitted by statutory regulation or exceeds the permitted use, you will need to obtain permission directly from the copyright holder. To view a copy of this licence, visit http://creativecommons.org/licenses/by/4.0/ 


\section{Introduction}

The Parvoviridae family comprises two subfamilies named Densovirinae and Parvovirinae; the latter afflicts vertebrates, and the Erythrovirus genus, and parvovirus B19 are its significant members [1]. The human parvovirus B19 is a small, linear, and single-stranded DNA virus. The unexpected discovery of this virus was first reported by Cossart et al. in 1975; it was found when the donor sera were being tested for hepatitis B virus $[2,3]$. It is mentioned that respiratory droplets are the means for the transmission of the B19 virus, and close contacts like household contact are also the other possible ways $[4,5]$. B19 can pass through the placenta and infect the baby. Moreover, it is likely to be transmitted through blood transfusions [6, 7].

Sickle cell disease (SCD) is an inherited monogenic hematological disorder. Homozygous missense mutations in the hemoglobin $\beta$-chain gene lead to the generation of sickle hemoglobin ( $\mathrm{HbS})$, and it is also responsible for chronic damage to various organs $[8,9]$. These mutations lead to thymine and glutamic acid substitution to adenine and valine, respectively [10]. In hypoxemia condition, $\mathrm{HbS}$ reduces the flexibility of RBCs (red blood cells) [11]. As a result, these fragile RBCs will increase the hemolysis and lead to chronic anemia [9].

Furthermore, sickled erythrocytes disrupt the blood flow in small capillaries and lead to a variety of disorders [11]. Thalassemia is a hereditary hematological syndrome with deficits in the production of one or more globin chains. The clinical characterizations are diverse, ranging from hypochromia and microcytosis to hemolytic anemia. The absence or reduction of $\beta$-globin chains happens in $\beta$-thalassemia patients $[12,13]$. Although major $\beta$-thalassemia patients need regular blood transfusions, it might cause a higher risk for B19 infection through blood transfusions [14-16]. Furthermore, B19 is thought to be a potentially life-threatening infectious agent in patients with high erythrocyte turnover [17]. By and large, this paper explores the prevalence rates of parvovirus B19 infection in sickle cell anemia and thalassemia patients based on the study inclusion criteria.

\section{Methods}

\section{Study design and search strategy}

This systematic review was carried out based on the criteria drafted in the Preferred Reporting Items for Systematic Reviews and Meta-Analysis (PRISMA) statement [18]. The PRISMA checklist was completed in all steps of this research. We did not register the study protocol before the initiation of the study.

In the current study, a literature search was performed in the English language from 1 January 2009 until 2019. The search process was performed in electronic databases, such as PubMed, Scopus, Web of Science, and Embase. For the search processing in the current study according to medical subject headings (MeSH), the following keywords were used "Thalassemia," "Parvovirus," "Anemia," "Sickle Cell anemia," "parvoviridae," "parvoviridae infection," "parvovirus B19." The reports were reviewed and managed with EndNote X8 (Thomson Reuters). The search was implemented by two independent researchers, and a third researcher checked the findings (Fig. 1).

\section{Inclusion and exclusion criteria}

The conducted search results were imported in EndNote Version X8 (Thomson Reuters), and the duplicate studies were removed. The screening was done according to the title and the abstract of articles, and finally, the fulltext was assessed. The administered inclusion criteria were as follows: (1) investigations in cross-sectional, cohort, and case-series design that monitored the B19 infection in sickle cell anemia and $\beta$-thalassemia patients (2) articles published in English language and between 2009 and 2019 and (3) observational studies were also included. All included articles met the inclusion criteria. Absence of significance and relevance of the data in the articles and the ones that did not meet the eligibility criteria were excluded. The non-representativeness of the study population and those studies utilized of nonstandard estimation devices were also removed. Moreover, case reports and case series with no significant sample size were excluded. These review articles (the literature reviews which were screened for relevant data), congress abstracts, and letters to the editor were excluded.

\section{Qualitative assessment}

All the eligible studies entered were evaluated for risk of bias utilizing the Critical Appraisal Skills Programme (CASP) checklist. The risk of bias in particular studies was ranked as low, moderate, and high. Studies with a high risk of bias were omitted.

\section{Data extraction}

To prevent bias, two independent reviewers doublescreened the final search results based on titles, abstracts, and full texts of articles according to inclusion and exclusion criteria. The third expert researcher solved the conflicts. The data of all included studies were summarized by using a data extraction sheet in EXCEL software, which covered the first author's name, country, publication year, thalassemia or sickle cell disease patients, thalassemia type, sample size, age, sex, IgG, and IgM prevalence, B19 virus genotypes, serological (ELIS A), and molecular (PCR) diagnostic methods and study design. 


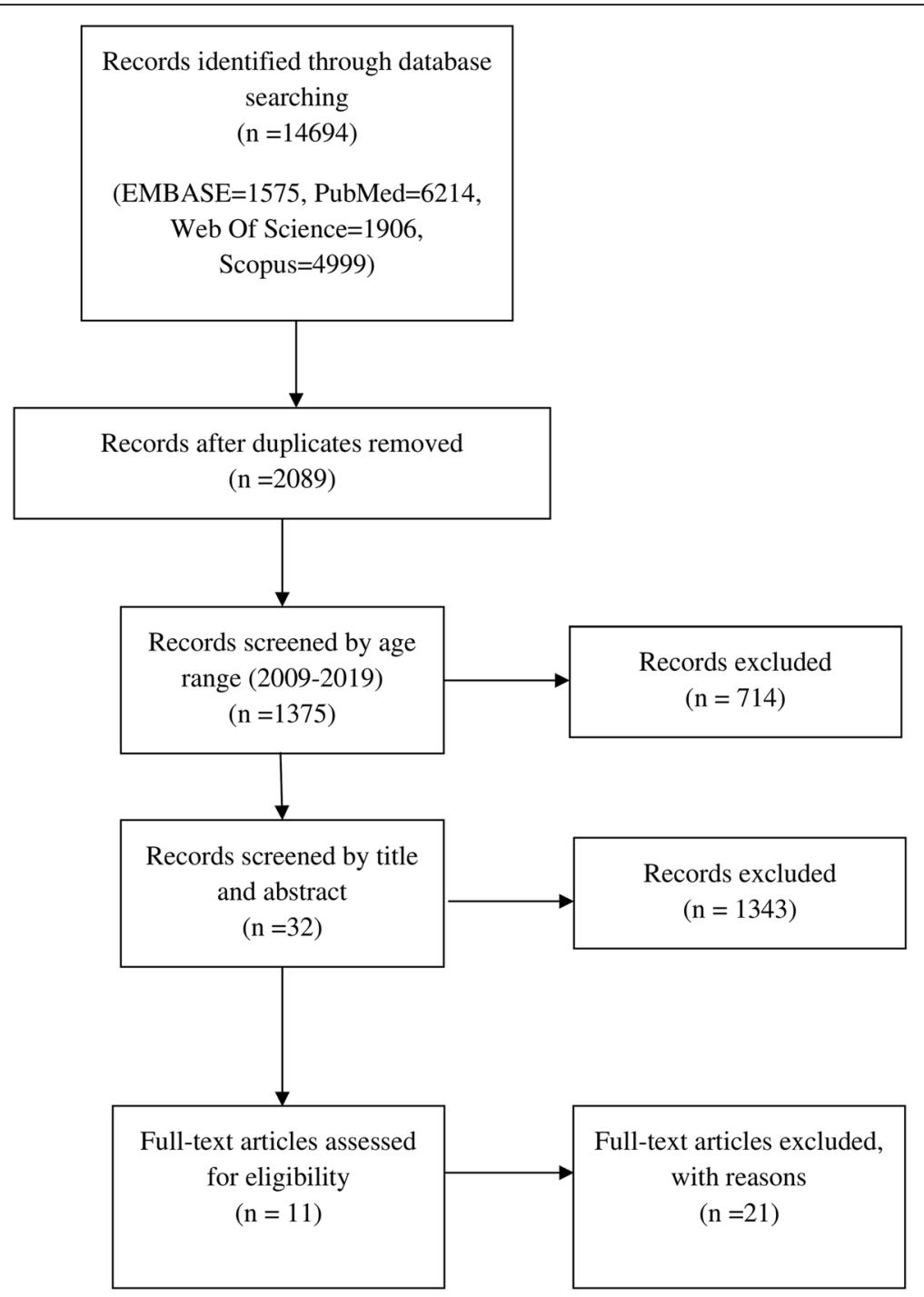

Fig. 1 Conducted study search flowchart

\section{Results}

In this literature review, the results of eleven different studies that assessed the parvovirus B19 infection in two different groups of patients were compiled. The conducted search result is illustrated in Fig. 1. Also, four studies evaluated general factors in patients with thalassemia. Six studies focused on patients with SCD. One study assessed parvovirus in patients with either thalassemia or sickle cell disease. Overall, 334 thalassemia and 1016 SCD patients were identified in these articles. The results were summarized in Tables 1 and 2. The following studies were published between 2011 and 2017.

\section{Parvovirus B19 estimated prevalence in beta-thalassemia major patients}

Among four studies focused on the prevalence of the parvovirus B19 in $\beta$-thalassemia, beta-thalassemia patients' lowest mean age was $6.2 \pm 13.25$ years in Egypt, and the highest mean age degree was 30.4 years in Iran. However, considering the mean age result between beta-thalassemia patients, most cases were in childhood. The B19V seroprevalence is dependent on age, and it rises steadily from early childhood to the elderly. Presumably, some of the included studies in our review, from the India Province, showed an association between the prevalence of parvovirus B19 infection and several factors such as childhood age, poor socio-economic conditions, and overpopulation.

Taking these four studies into account, it is noteworthy that in 184 patients, the anti-B19V IgG in $\beta$ thalassemia patients ranged from 18.2 to $81 \%$. The result of three different studies indicates that the anti-B19V IgM in $\beta$-thalassemia patients ranged from 14.5 to $41.1 \%$ in 145. Furthermore, the B19V DNA predominance rate was shown to be $4-15.3 \%$ in 189 patients. 


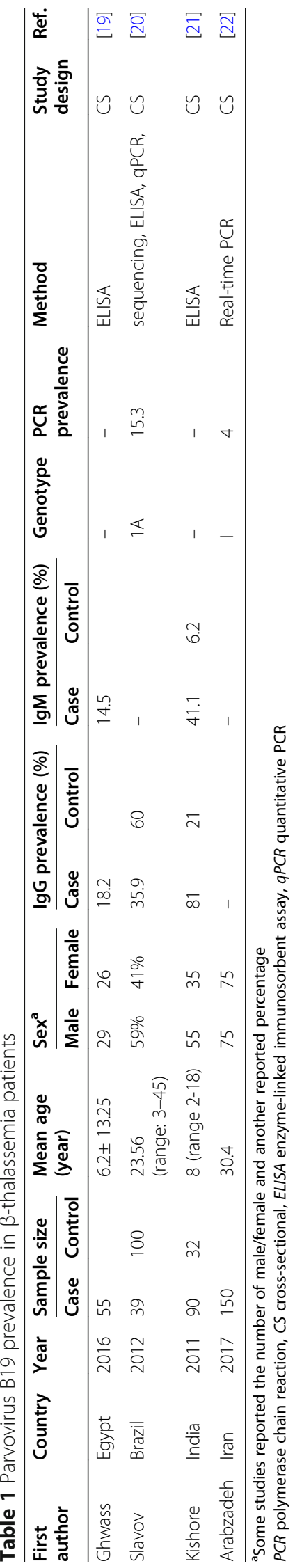




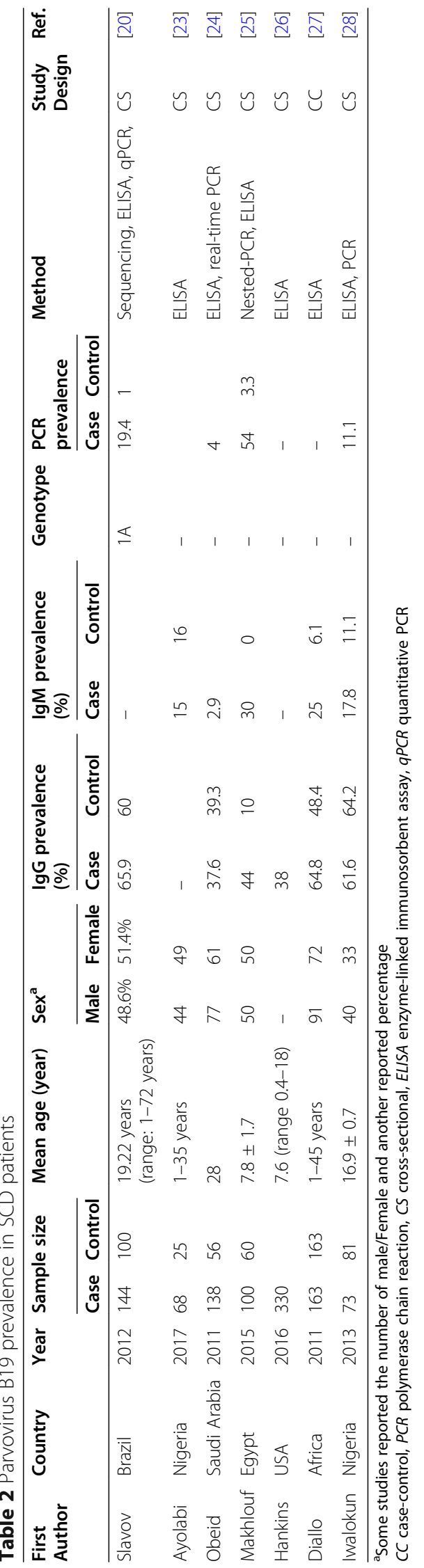




\section{Parvovirus B19 prevalence in SCD patients}

Seven different studies focused on the prevalence of the parvovirus B19 in SCD were taken into consideration. The mean age of SCD patients showed different ranges in economically developing countries such as Nigeria $(16.9 \pm 0.7$ years $)$ and rich countries like Saudi Arabia, i.e., 28 years.

\section{Anti-B19V IgM}

In six different studies, the anti-B19V IgG levels in SCD patients' sera was varied from 37.6 to $65.9 \%$ in 948 patients. Furthermore, in five different studies, it was indicated that the anti-B19V IgM in SCD patients ranged from 2.9 to $30 \%$ in 542 patients. The parvovirus B19 DNA predominance rate was $4-54 \%$ in 455 patients in four separate studies.

\section{Discussion}

Human parvovirus B19, the causative agent for erythema infectiosum (fifth disease), has a tropism for erythroid progenitor cells, and in consequence, it can temporarily suppress erythropoiesis in bone marrow $[29,30]$. In SCD and Thalassemia patients, the parvovirus B19 infection makes more severe conditions, known as a transient aplastic crisis $[20,31]$. The $\beta$ thalassemia patients have a higher risk for the infection of the parvovirus B19 due to the necessity of multiple blood transfusions throughout their life [32]. In the study carried out by Kishore et al. in northern India, the frequency of parvovirus B19 infection was assessed in 90 major $\beta$-thalassemia patients with a hyper-transfusion regimen who had 10-360 units of blood transfusion in their whole life and 32 controls. The results of the study indicated that the age range of participants was $2-18$ years, and $61 \%$ were males. In house ELISA for VP-1 and VP-2 was used to detect anti-B19 IgM/IgG antibodies; it revealed that the parvovirus IgG and IgM prevalence in major $\beta$ thalassemia patients were $81 \%$ and $41 \%$, respectively. It was also suggested that the seroprevalence of the parvovirus infection and the numbers of blood transfusion times are directly proportional [21]. Furthermore, Arabzadeh and colleagues investigated blood samples of $150 \quad \beta$-thalassemia major patients (75 males, 75 females) by real-time PCR to determine the prevalence of parvovirus B19 DNA. This study's results indicate that $4 \%$ of enrolled patients were positive for parvovirus B19 DNA, and half of these participants were aged 26-30 years and others were $31-35$ [22].

The academic community has extensively explored the titer of B19 IgG and IgM in SCD patients. Having said that, Ayolabi et al. investigated the level of parvovirus B19 IgM antibody in 68 SCD patients and 25 control samples by ELISA. Anti-parvovirus B19 IgM was detected in $15 \%$ of SCD patients. Also, Obeid assessed the parvovirus B19 antibody and DNA in 138 SCD patients. Obeid's study showed that the parvovirus B19 IgG and IgM prevalences are $37.6 \%$ and $2.89 \%$, respectively. Moreover, the parvovirus B19 DNA was detected in all IgM positive patients [24]. In another study in Egypt, Makhlouf et al. assessed the serological and molecular prevalence of the parvovirus B19 in 100 SCD patients and 60 controls. The results revealed that $30 \%$ of SCD patients were positive for the parvovirus B19 IgM and DNA, while $24 \%$ had positive IgG and DNA by nestedPCR [25].

Parvovirus B19 seroprevalence alters in various countries due to different causes. Hankins et al. reported that the incidence of parvovirus B19- specific antibody responses in pediatric SCD cases is expanded with age, as suspected due to an increased likelihood of parvovirus B19 exposure [26]. In the Arabzadeh et al. study, parvovirus-infected patients' mean age was 30.4 years [22]. The epidemiological aspects can affect the B19V seroprevalence in different groups of patients. Although this epidemiological division shows the immune response to B19V, it confirms the risen viral dissemination between elderly patients with SCD [20]. Reinfection is another relevant factor in maintaining B19V seroprevalence [20]. The different genotypes can influence antibody-positive and DNA-positive samples in different countries of Europe and Africa [24]. Kishore et al. reported no significant associations between parvovirus prevalence and thalassemia patients' age and gender. They mentioned that the B19V seroprevalence was raised to the low socio-economic status or a higher abundance of transfusions received by these patients [21]. Prior investigations queried the factors impacting on its seroprevalence. Ghwass et al. stated that the differences in B19V seroprevalence in different areas are dependant on the climate, variable socio-economic status, overpopulation, geographical, and the variety in the immunological-hematological status of patients [19].

The differences in all these studies could be due to the differences in the sample size and geographical distribution. This study was conducted as a preliminary study that could be useful for further systematic review and meta-analysis by narrowing it in this field of study. It could be used entirely as a reminder for more protective actions about parvovirus B19 transmission in susceptible patients. The drawback of this framework was the absence of quantitative analysis

\section{Conclusion}

Parvovirus B19 seroprevalence changes in several conditions in different countries and communities. The 
age can expand the incidence of anti-B19V $\operatorname{IgG} / \operatorname{IgM}$ in SCD and beta-thalassemia patients. Also, the epidemiological features can affect the B19V seroprevalence in groups of patients. Reinfection and diverse genotypes are additional relevant criteria in maintaining B19V seroprevalence and DNA-positively results. However, the differences in $\mathrm{B} 19 \mathrm{~V}$ seroprevalence in different areas are dependent on the socio-economic situation and overpopulation. Additionally, the difference in patients' immunological-hematological condition and higher abundance of transfusions received by patients are other factors that affect the $\mathrm{B} 19 \mathrm{~V}$ seroprevalence. Further investigations in the field of SCD or thalassemia and $\mathrm{B} 19 \mathrm{~V}$ infection is suggested to gain a better understanding of the virus distribution in susceptible populations.

\section{Abbreviations}

SCD: Sickle cell disease; IgG: Immunoglobulin G; IgM: Immunoglobulin M; B19V: Parvovirus B19; RBCs: Red blood cells; PCR: Polymerase chain reaction; CS: Cross-sectional; CC: Case-control; ELISA: Enzyme-linked immunosorbent assay; GPCR: Quantitative PCR; VP: Viral protein

\section{Acknowledgements}

We are sincerely thankful to our counsellors in Clinical Research Development Center of Shahid Mohammadi Hospital.

\section{Authors' contributions}

AF, SS, and AZ were primarily responsible for data collection and the study conception and design. Material preparation and analysis were performed by $A T, M Z, E E, S A R, S K, S S$, and AF. The first draft of the manuscript was written by AZ, MAN, SA, SS, and AF. All authors reviewed and approved the manuscript.

\section{Funding}

The present study is funded by Hormozgan University of Medical Sciences, Bandar Abbas, Iran (grant no. 980236). The supporting organization has no role in the design of the study and collection, analysis, and interpretation of data and in writing the manuscript.

\section{Availability of data and materials}

All data associated with this manuscript is inclusive in this paper.

Ethics approval and consent to participate

Not applicable.

\section{Consent for publication}

Not Applicable.

\section{Competing interests}

The authors report no conflicts of interest in this work.

\footnotetext{
Author details

'Department of Virology, School of Public Health, Tehran University of Medical Sciences, Tehran, Iran. ${ }^{2}$ Department of Hematology, Faculty of Medical Sciences, Tarbiat Modares University, Tehran, Iran. ${ }^{3}$ Department of Virology, Iran University of Medical Sciences, Tehran, Iran. ${ }^{4}$ Department of Health Care Management and Economics, School of Public Health, Tehran University of Medical Sciences, Tehran, Iran. ${ }^{5}$ Pediatric Surgery Research Center, Research Institute for Children's Health, Shahid Beheshti University of Medical Sciences, Tehran, Iran. ${ }^{6}$ Department of Cellular and Molecular Biology, Faculty of Life Sciences and Biotechnology, Shahid Beheshti University G.C, Tehran, Iran. ${ }^{7}$ Infectious and Tropical Diseases Research Center, Hormozgan Health Institute, Hormozgan University of Medical Sciences, Bandar Abbas, Iran.
}

Received: 15 September 2020 Accepted: 9 November 2020

Published online: 02 December 2020

\section{References}

1. MAM CF, Maniloff J, Desselberger U, Ball LA. Virus taxonomy, classification, and nomenclature of viruses. In: CM Fauquet, editor. The eighth report of the International Committee on Taxonomy of Viruses. San Diego: Elsevier Academic Press; 2005. p. 655-68.

2. Katta R. Parvovirus B19: a review. Dermatologic clinics. 2002;20(2):333-42. https://doi.org/10.1016/s0733-8635(01)00013-4.

3. Cossart YE, Field AM, Cant B, Widdows D. Parvovirus-like particles in human sera. Lancet. 1975;1(7898):72-3. https://doi.org/10.1016/s01406736(75)91074-0.

4. Pickering L, Baker C, Long S, McMillanassociate J. Parvovirus B19 (erythema infectiosum, fifth disease). Red Book: 2012 Report of the Committee on Infections Diseases; 2006. p. 539-41.

5. Servey JT, Reamy BV, Hodge J. Clinical presentations of parvovirus B19 infection. Am Fam Physician. 2007;75(3):373-6.

6. Chen MY, Yang SJ, Hung CC. Placental transmission of human parvovirus 4 in newborns with hydrops, Taiwan. Emerg Infect Dis. 2011;17(10):1954-6. https://doi.org/10.3201/eid1710.101841.

7. Wu CG, Mason B, Jong J, Erdman D, McKernan L, Oakley M, et al. Parvovirus B19 transmission by a high-purity factor VIII concentrate. Transfusion. 2005; 45(6):1003-10. https://doi.org/10.1111/j.1537-2995.2005.04387.x.

8. Rees DC, Williams TN, Gladwin MT. Sickle-cell disease. Lancet. 2010; 376(9757):2018-31. https://doi.org/10.1016/S0140-6736(10)61029-X.

9. Ware RE, de Montalembert M, Tshilolo L, Abboud MR. Sickle cell disease. The Lancet. 2017;390(10091):311-23.

10. Ingram VM. A specific chemical difference between the globins of normal human and sickle-cell anaemia haemoglobin. Nature. 1956;178(4537):792-4.

11. Piel FB, Steinberg MH, Rees DC. Sickle cell disease. The New England journal of medicine. 2017;376(16):1561-73. https://doi.org/10.1056/NEJMra1510865.

12. Muncie HL Jr, Campbell J. Alpha and beta thalassemia. Am Fam Physician. 2009;80(4):339-44.

13. Cao A, Galanello R. Beta-thalassemia. Genet Med. 2010;12(2):61-76. https:// doi.org/10.1097/GIM.0b013e3181cd68ed.

14. Zanella A, Rossi F, Cesana C, Foresti A, Nador F, Binda AS, et al. Transfusiontransmitted human parvovirus B19 infection in a thalassemic patient. Transfusion. 1995;35(9):769-72. https://doi.org/10.1046/j.1537-2995.1995. 35996029163.x.

15. Regaya F, Oussaief L, Bejaoui M, Karoui M, Zili M, Khelifa R. Parvovirus B19 infection in Tunisian patients with sickle-cell anemia and acute erythroblastopenia. BMC Infect Dis. 2007;7(1):123. https://doi.org/10.1186/ 1471-2334-7-123.

16. Langar H, Triki H, Gouider E, Bahri O, Djebbi A, Sadraoui A, et al. Infections par des virus transmissibles par le sang chez des hémophiles en Tunisie Blood-transmitted viral infections among haemophiliacs in Tunisia. Transfusion Clinique et Biologique. 2005;12:301-5.

17. Young NS, Brown KE. Parvovirus B19. New England Journal of Medicine. 2004;350(6):586-97.

18. Moher D, Liberati A, Tetzlaff J, Altman DG, Group P. Preferred reporting items for systematic reviews and meta-analyses: the PRISMA statement. PLoS Med. 2009;6(7):e1000097. https:/doi.org/10.1371/journal.pmed.1000097.

19. Al Ghwass ME, El Shafei SM, Mohamed WS, Mohamed BS. Seroprevalence of parvovirus B19 infection in patients with beta thalassemia major in Fayoum University Hospital. Egyptian Pediatric Association Gazette. 2016;64(3):126-30.

20. Slavov SN, Haddad SK, Silva-Pinto AC, Amarilla AA, Alfonso HL, Aquino VH, et al. Molecular and phylogenetic analyses of human Parvovirus B19 isolated from Brazilian patients with sickle cell disease and beta-thalassemia major and healthy blood donors. J Med Virol. 2012;84(10):1652-65. https:// doi.org/10.1002/jmv.23358.

21. Kishore J, Srivastava M, Choudhury N. Serological study on parvovirus B19 infection in multitransfused thalassemia major patients and its transmission through donor units. Asian J Transfusion Sci. 2011;5(2):140.

22. Arabzadeh SA, Alizadeh F, Tavakoli A, Mollaei H, Bokharaei-Salim F, Karimi $G$, et al. Human parvovirus B19 in patients with beta thalassemia major from Tehran, Iran. Blood Res. 2017;52(1):50-4. https://doi.org/10. 5045/br.2017.52.1.50.

23. Ayolabi Cl, Onwuzo SS, Ejere JA, Ibemgbo SA, Solanke TO. Detection of parvovirus B19 lgM in patients with sickle cell disease in Lagos, Nigeria. Asian Pac J Trop Dis. 2017;7(7):430-2. 
24. Obeid OE. Molecular and serological assessment of parvovirus B19 infections among sickle cell anemia patients. The Journal of Infection in Developing Countries. 2011;5(07):535-9.

25. Makhlouf MM, Elwakil SG, Ibrahim NS. Molecular and serological assessment of parvovirus B-19 infection in Egyptian children with sickle cell disease. J Microbiol Immunol Infect. 2017;50(5):565-9. https://doi.org/10.1016/j.jmii. 2015.10.016.

26. Hankins JS, Penkert RR, Lavoie P, Tang L, Sun Y, Hurwitz JL. Original Research: Parvovirus B19 infection in children with sickle cell disease in the hydroxyurea era. Exp Biol Med (Maywood). 2016;241(7):749-54. https://doi. org/10.1177/1535370216636723.

27. Diallo DA, Guindo A, Dorie A, Djibo N, Algiman E, Ouane OD, et al. Human parvovirus B19 infection in sickle cell anemia patient in Mali: a case-contro study. Arch Pediatr. 2011;18(9):962-5. https://doi.org/10.1016/j.arcped.2011. 06.019 .

28. Iwalokun BA, Iwalokun SO, Hodonu SO. Seroprevalence of parvovirus B19 antibodies and evidence of viremia among Nigerian patients with sickle cell anemia. Journal of biomedical research. 2013;27(4):272.

29. Young NS, Brown KE. Parvovirus B19. The New England journal of medicine. 2004;350(6):586-97. https://doi.org/10.1056/NEJMra030840.

30. Wong S, Zhi N, Filippone C, Keyvanfar K, Kajigaya S, Brown KE, et al. Ex vivogenerated CD36+ erythroid progenitors are highly permissive to human parvovirus B19 replication. Journal of virology. 2008;82(5):2470-6.

31. Singhal L, Mishra B, Trehan A, Varma N, Marwaha R, Ratho RK. Parvovirus b19 infection in pediatric patients with hematological disorders. J Glob Infect Dis. 2013;5(3):124. https://doi.org/10.4103/0974-777X.116881.

32. Plentz A, Hahn J, Knöll A, Holler E, Jilg W, Modrow S. Exposure of hematologic patients to parvovirus B19 as a contaminant of blood cell preparations and blood products. Transfusion. 2005;45(11):1811-5.

\section{Publisher's Note}

Springer Nature remains neutral with regard to jurisdictional claims in published maps and institutional affiliations.

Ready to submit your research? Choose BMC and benefit from:

- fast, convenient online submission

- thorough peer review by experienced researchers in your field

- rapid publication on acceptance

- support for research data, including large and complex data types

- gold Open Access which fosters wider collaboration and increased citations

- maximum visibility for your research: over $100 \mathrm{M}$ website views per year

At $\mathrm{BMC}$, research is always in progress.

Learn more biomedcentral.com/submissions 